\title{
Introduction: the growth of ignorance?
}

\author{
Introduction to
}

An Anthropological critique of development:

the growth of ignorance?

ed. Mark Hobart

London: Routledge, September 1993

Mark Hobart,

Department of Anthropology and Sociology,

School of Oriental and African Studies,

University of London,

Thornhaugh Street,

Russell Square,

London WC1H 0XG.

(C) Mark Hobart 1993 
The relationship of Africa, Asia and Latin America to Europe and North America in the post-war period is often couched in the language of development. Something seems to be amiss however. Granted the vast sums invested in trying to find a solution to what is described as the problem of underdevelopment, by the criteria of the development planners matters should be getting better rather than worse. Instead it would seem that development projects often contribute to the deterioration. A largely neglected aspect of such development is the part played by western scientific knowledge. Not only are indigenous knowledges ignored or dismissed, but the nature of the problem of underdevelopment and its solution are defined by reference to this world-ordering knowledge. Anthropologists have long been among those who have questioned whether such scientific knowledge is as all-encompassing and efficacious as its proponents claim. So it is apposite that the contributors to this collection, who are critical of the workings of scientific knowledge in processes of development, should be anthropologists. The aim is not to offer a solution to the problem of development, which has been notoriously elusive. Development is effectively a synonym for more or less planned social and economic change. So, defining development as a problem susceptible of a solution, or pathologically as a condition requiring a cure, may well be misplaced. In the essays which follow the contributors question the presuppositions which inform much discussion of development and explore the relationship between scientific knowledge and local knowledges in practice. As systematic knowledge grows, so does the possibility of ignorance. ${ }^{1}$ Ignorance however is not a simple antithesis of knowledge. It is a state which people attribute to others and is laden with moral judgement. So being underdeveloped often implies, if not actual iniquity, at least stupidity, failure and sloth.

\section{Some introductory observations}

Because the prevailing rhetoric is of altruistic concern for the less fortunate, it is wise to remember that development is big business. Development aid, including loans, probably dwarfs in scale many multi-national industries or the Mafia. In one form or another, development is very profitable not just to the western industries involved, but to those parts of governments which receive aid, let alone to development agencies. And the giving of development aid and the extension of markets for manufactured products is more than balanced by the processes of counter-development, by which the countries to be developed make up the major source of cheap raw materials and labour. Less obviously, the idea of 'underdevelopment' itself and the means to alleviate the perceived problem are formulated in the dominant powers' account of how the world is. The relationship of developers and those to-be-developed is constituted by the developers' knowledge and categories, be it the nation state, the market or the

\footnotetext{
${ }^{1}$ I am particularly grateful to Richard Fardon for first pointing out to me that, as knowledge is usually constituted, the growth of knowledge entails the growth of ignorance, and for reading the draft of this Introduction. I would also like to thank Lisa Croll, Philip Quarles van Ufford and Piers Vitebsky for their valuable comments; Ron Inden for a useful discussion of some of the general themes; Raymond Apthorpe for his continued interest and enthusiasm; and Nanneke Redclift who read the manuscript and whose positive comments were a great encouragement. My special thanks are due to the late Anthony Forge and Cecilia Forge for their hospitality and kindness in explaining some of the arcane mysteries of development projects at work.
} 
institutions which are designed to give a semblance of control over these confections. The epistemological and power aspects of such processes are often obscured by discourses on development being couched predominantly in the idiom of economics, technology and management. What is signally absent in most public discussion of development are the ways in which the knowledges of the peoples being developed are ignored or treated as mere obstacles to rational progress. ${ }^{2}$ In order for them to be able to progress, these peoples have first to be constituted as 'underdeveloped' and ignorant. Conversely, without such underdevelopment and ignorance, the west would not be developed and possess knowledge.

Such ascriptions are not however self-evident, but are part of a long history of changing western representations of other societies. A striking feature of these representations is that they are often agentive. By this I mean that they depict a state of affairs requiring action or intervention of some kind, usually by the party doing the depicting. At various times the peoples of much of the world have been portrayed as savage, decadent or merely pagan and unenlightened. So they require law and order, effective government or Christianity and civilization. Whatever the rationale, nonwestern societies have been widely represented as static, passive and incapable of the progress based on rational government and economic activity which the West alone could provide. The difficulties of planned economic and social development are not simply the work of self-interested industries and governments. The social and historical vision of the world order, and the rationality which subtends it, has been in no small part constituted and justified by academic writings. ${ }^{3}$ Insofar as such accounts are adopted by the governments or people of developing countries as constitutive of their aspirations, they are hegemonic in Gramsci's sense (e.g. 1988: 189-221).

There are more prosaic difficulties with processes of development. First, by most standards of judgement including the professed goals of the developers, most development projects fall seriously short. For instance, in the much-vaunted project to irrigate the drought-prone Sahel region in Africa, for each 5,000 hectares of land brought under irrigation, exactly the same amount of previously irrigated land was turning into salty desert, because of poor drainage. ${ }^{4}$ An allied problem is the presumption in the priority of technology over social considerations. In Timor in Indonesia, it rains heavily for some three months of the year, and is very dry for the remaining nine. So a large dam building project was carried out to bring water to particularly arid areas. When I was there six beautiful ecologically sensitive dams had been finished. None was being used by the population it was supposed to serve. The dams had been built in the best places to build dams. Unfortunately no one lives within many miles. There is a twist to the tale. Coincidentally or otherwise, the dams were mostly near roads. So, if people migrated to where water was, government would be

\footnotetext{
${ }^{2}$ There are of course exceptions, such as Brokensha et al. 1980; Chambers 1983. Both works however tend to hypostatize local practices into 'indigenous knowledge systems', an approach with which I take issue below.

${ }^{3}$ More detailed accounts of such representations and the rôle of western scholars in formulating them are to be found in Alatas 1977; Said 1978; Pagden 1982; Fardon 1990; Inden 1990; Mason 1990. Most of these authors make use in some way of the work of Michel Foucault (especially perhaps 1961, 1966, 1975, 1976), whose approach more implicitly informs the Introduction and a number of essays in this volume.

${ }^{4}$ This example is cited by Timberlake 1988: 61. He notes that the vice president of the World Bank for policy, planning and research, David Hopper, an ex-anthropologist, has castigated 'the anomaly of economic calculus' responsible for the massive damage done in the name of development (1988: 60).
} 
able to keep an eye on them, rather than them remaining in the hills where no one could easily check what they were up to. Such instances abound; and several are documented in the essays below.

However, the problems are not simply the failure to achieve sustainable development, or that technological or economic concerns often prevail over social considerations. There is little link at times between the theory of rationally planned development and the implementation of development policies. Such disjunctures are commonly explained as due to the need to specify theory in practice. They may more accurately be seen though as the limitations of a paradigm, which combines an idealist theory of rationality and a naturalist epistemology. It has proven ill-suited to explain, let alone deal with, processes which are non-natural and involve reflexivity on the part of the human beings concerned. A prime example is the difficulties of coping with unintended consequences, the nemesis of so much elegant and theorizing, when it encounters practice. ${ }^{5}$

Needless to say these difficulties have little impact on either the formulation of development policy, still less on the paradigm itself. As Quarles van Ufford and Long (forthcoming) note, the rhetorical appeal of policy formulation is aimed at western governments and other donors as the developers' main constituencies, not at the 'targets' of development. For this reason among others, the evaluation of the effectiveness of projects has been slow to develop, where criteria of success are problematic anyway. ${ }^{6}$ Further, knowledge, especially technical knowledge, is widely treated as a valued commodity to be sold or otherwise transferred. It would be poor marketing to question its worth, or whether it is a commodity at all. More generally, scientific epistemology, which underwrites development theories, is far less empirical than is supposed (Quine 1953) and, as we shall see, contrary experience can always be accounted for without threatening the paradigm as a whole. A similar point has been made by Winch in a neat parody of Evans-Pritchard's classic study of Zande witchcraft (1937) as a closed system of beliefs impervious to ostensibly contrary evidence, when he notes that the same can be said of western science (1970: 89).

The position adopted by the contributors to this collection, all of whom are anthropologists with extensive field experience of development in some form, is that claims to knowledge and the attribution of ignorance are central themes to development and remain seriously under-studied. Rather than offer yet more generalization to debates on development, they all focus on how kinds of knowledge, western and local, are used in practice. Broadly they treat knowledge not as some abstract conceptual system, but as situated practices. They also take issue with the idea that such practices form 'systems' of indigenous knowledge, although this does not imply that there are

\footnotetext{
5 Some of the problems of unintended consequences are outlined in Fabian's critique of reason and western epistemology (1991: 189-98). The way such epistemologies serve to distance others, to deny them coevalness and make them objects or victims rather than subjects and agents is discussed in Fabian 1983. Some of the shortcomings of natural scientific and rationalist epistemologies are discussed in Quine 1953; Feyerabend 1975; Goodman 1978; Habermas 1978; Rorty 1980; Hacking 1983; and Taylor 1985.

${ }^{6}$ A good example was presented to the original conference by Till Forster. A development agency had undertaken to increase cattle production for marketing among the Poro of the North Ivory Coast. They left, regarding the project as highly successful, because they had succeeded in their aim. Not long after, the Poro with whom Forster worked said they felt it was a disaster. This was both because overgrazing occurred and because the greater number of cattle, which were used in bridewealth payments, brought havoc to marriage arrangements.
} 
not written canons such as Indian Ayurvedic medicine. I shall consider in detail below how the contributors represent local knowledges. For the moment it should suffice to note that they often appear to be more about 'knowing how' than 'knowing that' (Ryle 1949: 26-60), or 'knowing as' (Cohen p. 3 in this volume). They may perhaps usefully be considered as a 'performance' (Richards), as 'practical, factual, detailed and personal' (van Beek p. 15) and sensible to the particularities of place, occasion and circumstance. Contrary to popular representations, such knowledges are subject to testing and modification, involve theory (van der Ploeg p. 2) and metaphysical presuppositions, although not necessarily in the senses imagined in western analytical philosophy (Collingwood 1940; Hobart 1985a). Still less can they be dismissed, as often happens, as 'traditional' obstacles to rational progress and convenient 'scapegoats' to explain the failure of development programmes (von Benda-Beckmann).

While each of the contributors sets out to show the underestimated value of local knowledges, none of them however indulge in the (singularly western) romantic fantasy of the desirability, even were it possible, of a return to native wisdom mysteriously in touch with nature. Rather the stress is on the value of treating local knowledges seriously and examining their potential contribution to peoples' material, intellectual and general welfare. One feature which many of the contributors elaborate is the link of knowledge and agency. Local knowledges often constitute people as potential agents. For instance in healing, the patient is widely expected to participate actively in the diagnosis and cure. By contrast, scientific knowledge as observed in development practice generally represents the superior knowing expert as agent and the people being developed as ignorant passive recipients or objects of this knowledge.

\section{Some presuppositions of sociological theories of development}

Sociologists and anthropologists have long been critical of attempts to articulate development in purely economic or technological terms, and the assumptions which underlie them. In this section I shall argue however that, despite some well-rehearsed differences, sociological theories of development often involve presuppositions drawn from the same rational scientific epistemology. While these theories may be critical of certain assumptions of economists, the effect is to replicate the dominant epistemology in a subtler guise. ${ }^{7}$ To the extent that, as I argued above, hegemonic representations constitute the conditions of power, then these critics may unwittingly be caught up in helping to perpetuate what they claim to criticize. My aim here then is not a comprehensive review of theories of development, but a brief examination of some of their presuppositions and the way in which agency is represented. ${ }^{8}$

\footnotetext{
${ }^{7}$ This is Just how confused and incoherent the former are is made clear by Hahn \& Hollis 1979; and Dilley (in press) offers an excellent critique of economic discourse on 'the market'. Heath offers a straightforward account to the inadequacies of rational choice and exchange theory in economics, which he contrasts with more sensitive sociological accounts. The latter at least allow a measure of context and the recognition of relative, as opposed to absolute, value (1976: 44-50). Both accounts however presuppose a model of rationality on which there has been lengthy debate. I know of no good account of the presuppositions of sociological and anthropological theory, although Giddens 1976 is basic and quite useful.not the place to engage in the substantial undertaking of a critical analysis of the philosophical presuppositions of economic or sociological theory.

${ }^{8}$ There are already some good clear reviews of the subject, such as Long 1977, of whom I make use in what follows.
} 
Development has often been linked to, or equated with, modernization; that is the transformation of traditional societies into modern ones, characterized by advanced technology, material prosperity and political stability (e.g. Moore 1963). ${ }^{9}$ As elaborated by Smelser (1963), significantly economic development requires inter alia the modernization of technology through the application of scientific knowledge and a shift from subsistence farming to cash-cropping and wage labour. Modernization theory assumes a unidirectional evolutionary account of social change and is not based on actual case materials, but is 'an idealization of the main direction of certain social and cultural trends' (Long 1977: 26, citing Smith 1973: 87). It is not just that the categories of 'traditional' and 'modern' are vague and idealized constructions, but the process of development is defined teleologically by reference to the supposed state of the dominant party. The means to this transformation is scientific knowledge. Significantly such knowledge requires the homogenization and quantifiability of what is potentially qualitatively different. ${ }^{10}$ For instance, kinds of food become cash crops and human activities become labour. What is lumped together here is often regarded by the peoples concerned as heterogeneous and qualitatively diverse in practice. While the utility of treating human activities as labour for certain purposes is evident, such homogenization underwrites a linear evolutionary view of history (of which Marxist histories are as guilty as modernization theory) by ignoring the discontinuities and differences in discursive constructions of land, labour, the units or agents of economic decision making and the idea of economy itself (Tribe 1978). Whatever its merits, scientific knowledge applied to development is not neutral, as is so often claimed, nor are the implications of its use.

In modernization theory and others, society or culture is treated, suitably reified, as an 'obstacle' to change; more rarely as facilitating it. What is striking for an epistemology which claims to represent the world accurately and neutrally is the frequency with which abstract and contested notions not only make use of metaphor, but the extent to which metaphor is constitutive (see Ortony 1979). Not only is it inherent in the formulation, as here, of development theories; but knowledge itself is generally constituted around a metaphor, be it knowledge as a mirror, as a commodity, as a space for exploration or expansion (Salmond 1982). If one removes all explicit and implicit references to such metaphorical images, the degree to which many theories require modification or rethinking is remarkable. Society and culture are not obstacles to change, nor except loosely can they be said to facilitate change. Such accounts presuppose society or social relations as some hypostatized pseudo-entity. Arguably change is going on all the time and the problem, if any, is to account for the appearance of stasis. In whatever sense society may usefully be said to exist (on which see Bhaskar 1979, 1989), it is not an object or entity. As Hacking has argued at length (1990), the construction of such pseudo-entities came into vogue with the preoccupation with statistical theorizing in Western Europe in the nineteenth century, which was inextricably linked to the extension of control and surveillance of populations.

\footnotetext{
${ }^{9}$ Granted the scale of destruction wrought in two World Wars alone this century by the purveyors of this 'political stability', such a vision is a remarkable feat of wishful thinking.

${ }^{10}$ The trend towards standardization around the notion of 'the average' does violence to observable variation, as in the idea of the fertilizer or pesticide for the average field. On the tyranny of 'averages' and 'norms', see Hacking 1990; and their relevance to development in economic representations of landscape as a homogeneous expanse, see Vitebsky 1992: 242-44.
} 
The metaphors implicit in 'development' provide an apposite example. There is a certain entelechy in the notion of something unfolding or growing naturally to the fulfilment of a potentiality, the seeds or programme for which is already established. The refractions of such metaphors may vary between societies and languages. In Indonesia, for example, there are three potential words available. Perkembangan, from the root for 'flower', suggests growth which requires little external intervention. Kemajuan, 'progress', tends to be linked to western liberal economic and political ideas, with connotations of rationality. The third, pembangunan, from the root for 'get up, grow up, build' is the term favoured by government officials and developers because, as Quarles van Ufford points out,

this process does not realize itself automatically, but needs outside action or encouragement. So, the process of development cannot realize itself if careful guiding and cultivation do not take place' (1985: 57)

For the term 'development', metaphor does not merely illuminate, but is constitutive. The end state and the nature of the process is, partly at least, predefined or prescribed. It does not of course follow that the action prescribed by some account is fully determined. The adoption of pembangunan as the chosen idiom neatly combines entelechy with the need for guidance by those with power and knowledge, here the government officials who elaborated the notion in the first place.

To return to development theories, a problem of modernization theory is that it omits recognition of wider social and historical processes. This criticism is central to 'dependency theory', according to which structures of dependence are set up by the world capitalist system, which penetrates local societies and economies, and extends down to tie apparently remote workers to the system (e.g. Frank 1969). The use to metaphor to add impact is significant. First, there is a pervasive spatial metaphor of 'up/down', 'metropolitan centre/satellite', in which capitalism is portrayed as superior and central, or what below I describe as a 'transcendental agent'. ${ }^{11}$ This is capped by a sexual metaphor (capitalism 'penetrating'), in which the powerful, superior, male West imposes itself on weak, inferior, captivated (and female) others. Indeed there is a further carceral image (the 'tied' worker) of development as punitive, as against modernization theory's vision of development as reform (cf. Foucault 1975). It is hardly surprising therefore that dependency theory tends to underestimate locally motivated change and other kinds of relationships. Once again, social and economic institutions like 'capitalism' and 'class' are at once reified and abstracted from actual social and historical situations (Laclau 1971).

The corrective to such broad institutional analyses stresses the importance of individual entrepreneurs in economic and social change. Such accounts are almost always transactionalist, the anthropological resuscitation of utilitarianism, in which rational individuals set out self-interestedly to maximize their utility, whether defined as wealth, power or status (e.g. Bailey 1957, 1969; Barth 1963, 1966; cf. Paine 1974). The rejoinder is hardly unexpected. Collectivism and individualism in one form or another are entrenched intellectual positions in a long running battle. ${ }^{12}$ The dispute is

\footnotetext{
11 On the widespread use in English of orientational metaphors like height to suggest superiority, goodness, power etc., see Lakoff and Johnson 1980: 14-21.

${ }^{12}$ A famous rehearsal is the debate between Durkheim and Tarde (see Lukes 1973a: 302-13). The methodological argument of whether to explain action by reference to collectivities or individuals (see Lukes 1973b) is still alive in Hayek's (individualist) theory of monetarism. Giddens's attempt to
} 
somewhat phoney, because the alternatives presuppose and depend on one another more than is often recognized (Bhaskar 1979: 39-47).

Obviously much more could be, and has been, said about development theories. Because of their relevance to the theme of this volume, I am particularly concerned however with questions of explanation, especially the description (or prescription) of the nature of knowledge, rationality and agency, and their attribution. I deal with each in turn briefly.

It would be very convenient if, among rival theories, we could decide which was more or less correct, and also judge the rival merits of accounts based on western as against indigenous knowledge. While theories may sometimes be disqualified by failing to fit facts, often they are not fully verifiable or they account more or less adequately for the available evidence, so that there is no simple empirical method of judging between them. This underdetermination of theory by evidence, as Quine has made clear is because

the totality of our so-called knowledge or beliefs...is a man-made fabric which impinges on experience only at the edges... the total field is so underdetermined by its boundary conditions, experience, that there is much latitude of choice as to what statements to revaluate in the light of any single contrary experience.' (1953: 42-43)

Additional criteria are required to decide which theory to adopt (Hesse 1978). For developers, this is likely to be models which are generalizable or appear to offer the greatest predictability or the semblance of control over events. Developers are often asked to complete research and even projects within absurdly short time-spans. So they tend to have to work with pre-established guidelines and assume particular conditions fit a general mould. Charming absurdities can result. In the Timorese project mentioned, it is an established rule apparently that piping water costs $1 \%$ of the expenditure on dam construction. That this left taps in the middle of nowhere was neither here nor there. (Were local people to indulge in such thinking, they would be deemed irrational.) Anthropologists, on the other hand, have an obvious interest in explanatory accounts which are as compatible as possible with observable events and with the representations of events by the participants. ${ }^{13}$ Incommensurability between accounts of what is going on in development are not just theoretically possible, but are usually the case in practice. For anthropologists, this is part of their subject matter.

The historical and sociological aspects of scientific knowledge has increasingly been recognized (e.g. Kuhn 1962; Feyerabend 1975). The extent to which such knowledge is a social activity was neatly put by Peirce in 1868 .

the very origin of the conception of reality shows that this conception essentially involves the notion of a COMMUNITY, without definite limits, and capable of an indefinite increase in knowledge' (1984 (1868): 239; capitals in the original).

The criteria of what constitutes knowledge, what is to be excluded and who is designated as qualified to know involves acts of power (Foucault 1971). Once more prescriptions of the nature of knowledge and how the knower is constituted are strikingly metaphoric. As Rorty has pointed out, a presupposition in much western

combine the two (e.g. 1984) arguably leaves him with two sets of questionable presuppositions, which are additionally partly incompatible, rather than just one.

${ }^{13}$ My observations are preliminary, because the whole question of choice between rival theories is complicated and remains under-investigated. One might note however that issues of value are often used in choosing preferred explanations. So a particular political, moral or religious orientation is not necessarily an unwarranted imposition on neutral matters of fact, but one kind of criterion of choice. Anyway the supposed neutrality of scientific knowledge is misleading. 
epistemology is that the human mind is like a mirror which reflects reality and problems of accurate knowledge boil down to repairing the mirror (1980). The monopoly on this knowledge is held, in a rather inspecific way, by the west (another significantly imprecise term). Development consists in no small part of knowledge, positivitically conceived as true propositions about the world, being treated as a valuable resource. Both this latter commodity metaphor of knowledge and the mirror metaphor notably exclude the idea of knowing being a dialectical and critical process. Criticism in development tends to be a synonym for telling off the ignorant or lazy natives, not the crucial means to understanding or, more realistically, reducing the degree of misunderstanding. ${ }^{14}$

A related and important metaphorical representation, as Peirce noted, is of knowledge as growing. ${ }^{15}$ Apart from treating knowledge as a quasi-natural entity, the implicit entelechy gives a sense of inevitability and so superiority to those who master or are part of this process of growth. Remarkably, it seems to have largely slipped notice that the postulated growth of knowledge concomitantly entails the possibility of increasing ignorance. In development this is manifested practically in local knowledges being devalued or ignored, in favour of western scientific, technical and managerial knowledge. ${ }^{16}$ As we shall see when discussing agency, such constructions have implications for power in the ways in which people are differently constructed as subjects or objects, agents or patients, according to different kinds of knowledge. Perhaps I should note at this point that these criticisms of representations of scientific knowledge do not imply that it is not, and has not been, of great value and import. It is, following Collingwood (1933: 26-53), to note that scientific and philosophical knowledge (to which I would add historical and anthropological knowledge as well) are dialectically related, such that the latter serve critically to reflect on the implications and consequences of the former.

The idea of development as governed by rational progress has some similar implications to the image of knowledge growing. The whole issue of the nature and relevance of rationality to human action has been the subject of long debate involving philosophers and anthropologists (see Wilson 1970; Hollis and Lukes 1982; Overing 1985). For present purposes, a few observations will suffice. The relationship between theoretical and practical reason is unclear in practice. Advocates of some universal rationality disagree among themselves not only of what this rationality consists, but whether it is an a priori necessity of cognition and communication (Hollis 1970, 1982) or is establishable a posteriori from its evident success (e.g. Newton-Smith 1982).

\footnotetext{
${ }^{14}$ Misunderstanding is not simply explained by poor communication, but is an actively fostered process often by both sides (Benda-Beckmann). Many of the criticisms of those who are the objects of development are projections, such as the tendency to think in the short term and the search for magical solutions.

${ }^{15}$ Consider the title of the celebrated collection of essays criticizing Kuhn's work, Criticism and the growth of knowledge.

16 There is a long history of western philosophical bias in favour of episteme, theoretical knowledge, against techne, applied science, art, skill, which is geared to production (poietike) with the corresponding need for judgement (doxa) and even against the practical sciences (praktike) of politics and ethics. For

Scientific knowledge is judgement about things that are universal and necessary... This being so, the first principle from which what is scientifically known follows cannot be an object of scientific knowledge, of art, or of practical wisdom; for that which can be scientifically known can be demonstrated and art and practical wisdom deal with things that are variable... some even of the lower animals have practical wisdom' (Aristotle 1941: 1027-28).)

Even allowing for changing usage of terms, one could hardly be clearer.
} 
Even where rationality is defined narrowly by logic, there is disagreement over whether it is descriptive, prescriptive or a formal condition of thought about the world. Whether everyone shares this vision of the world as ultimately knowable through the exercise of reason, let alone whether they take decisions on this basis, is doubtful. Balinese for instance make use of a quite distinct form of reasoning (Hobart 1985a), but recognize both the importance of human feeling and attitudes, and the possibility that some matters may be unknowable to human beings, whose mental capacities are not limitless. ${ }^{17}$ Assertions of rationality should perhaps be regarded as ex post facto claims in particular situations and as part of social action.

The previous discussion is relevant to a problem which is increasingly being recognized as important in development projects and is often implicated in their failure. This is the nature of the understanding between the parties involved. The desired goal is usually expressed in terms of communication. 'In order to have development and to have people understand how development is to be applied to their particular case, developers need to communicate with "developees"' (Brokensha et al. 1980: 7). The implication is that, if both sides improve communication a major obstacle (sic) will be removed. Such a view is naïvely optimistic. Not only does it ignore the many reasons people may have for not wishing to communicate and indeed to want to dissimulate (e.g. Quarles van Ufford in this volume). It also rests upon a model of knowledge as communicable propositions and presumes rationality to be shared. The mirage of perfect communication presupposes communication to be the relatively simple business of transmitting knowledge as information between sender and receiver. (One might note that there is no obvious antonym of 'information', the antithetical terms being significantly 'misinformation', or even 'disinformation'.) Problems are conceived of mechanically and are held to arise where the code is not shared, there are difficulties in the medium and so on. Wallace has pointed out, however, all that is required is that the parties concerned can find equivalences of some kind. Not only do they not need to understand each other, but it is questionable how well social relations would work if people regularly did so (1961: 29-44). Such a model of communication assumes a 'conduit metaphor', in which language 'contains' meaning inserted by the speaker and extracted by the listener. Reddy has argued in favour of an alternative image of communication being a matter of degree and the end result of much mutual work (1979). This is close to what how I use the notion of understanding, which is inevitably always imperfect, dialectical and critical. ${ }^{18}$

Anthropologists' experience of what goes on in development projects seems better to fit an account of communication as requiring work. The social worlds of developers, whether foreigners or nationals, are almost always far apart from those being developed, as is the nature of their involvement, what is at stake and the perceived

\footnotetext{
${ }^{17}$ Quarles van Ufford (1985: 53-56) has a good discussion of the importance of feeling, rasa, and its link to mystery, rahsya, in neighbouring Java.

18 The position which I take is closer to Volosinov's (1973) or Bakhtin's (1986) vision of speech as situated acts. Significantly the word 'knowledge' in English has connotations of 'the passive content of what is known' by contrast to the German Erkenntnis and French connaissance, which emphasize 'the act, process, form, or faculty of knowing' (Shapiro 1972: 319). I discuss the contrast between knowing and understanding in some detail in Hobart forthcoming.

The trend in development projects towards more direct 'participation' or 'involvement' rests upon the presupposition that this will somehow improve communication, which is questionable. At least 'participation' - if it involves knowing the relevant languages, and the social and cultural context - does not preclude the possibility of less misunderstanding.
} 
purpose of the enterprise (Arce and Long). Even where developers have sufficient command of language to speak and listen, the relationship of developers and developed are usually regarded as hierarchical by both parties. So communication easily becomes the giving of information or instructions by those with expert knowledge. And all too often the only effective means of disagreement is silence or the refusal to engage in enterprises as defined by the superior party, who may treat those to be developed as invisible anyway (van der Ploeg p. 12). For these reasons, it is convenient to talk of there being several coexistent discourses of development. By 'discourse' here, I am adapting Foucault's term for the regularities of what is said and done, including importantly the conditions of knowledge and power with its inevitable closures (see esp. 1972: 21-76). Although discourse is a difficult notion, which seems to work best on grand-scale historical reconstructions, it does draw attention to the differential working of knowledges and powers in practice. This includes notably prevailing metaphors of knowledge and communication, and of the nature of power. In this sense then it may be useful to distinguish for the moment at least three discourses, which may partly overlap. Apart from the professional discourse of developers and the discourse of the local people being developed, the national government and its local officials commonly also have distinctive powers and forms of enshrined knowledge, with their concomitant closure ${ }^{19}$. Just how separate and indeed incommensurable are the respective discourses of developers, developed and governments is a striking feature of many of the essays in this volume.

We have seen how constructions of knowledge may be agentive, in that they indicate who is qualified to know and act, and who not. They may also indicate the course or nature of the action to be taken. It is instructive briefly to review some of the theories of social development outlined above in this light. Most theories emphasize the need for planned change. In other words, existing organizations cannot achieve the desired goals on their own. So how are these organizations conceived and what form of necessary agency is postulated? In modernization theory the stress is on the deficiencies of traditional institutions which people, treated as passive objects, are incapable of changing. Dependency theory likewise construes people as the passive victims of forces over which they have no control, here the capitalist market economy. According to the former the problem is the absence of agents; according to the latter a nigh omnipotent and alien agent. The agency for change in either case must therefore come from planners, who have a superior understanding of the structures responsible and capacity to change or replace them.

At first sight both theories might seem to aim to make previously passive objects agents. This is however not so. Closer inspection shows that the diffusion of modern technology is supposed to provide an example (a 'demonstration effect') to 'progressive' farmers. Or, more radically, progressive elements will rise to meet the demands and opportunities of new structures. In other words, the populace is constituted as willing subjects, the planners provide the intelligence about the workings of the modern economy or the will of the revolution, but determine neither. The ultimate agents are therefore transcendental, various groups of humans making up the instruments through which they work. The point is perhaps clearer if we consider the transactionalist approach or its avatar, the New Right's emphasis on the market as the

19 It may be helpful to consider other major institutionalized discourses, for instance in Latin America that of the catholic church. 
sufficient condition of change. Once again agency at first seems vested in the enterprising individual. But he or she only responds to market forces, the patterns of which are elucidated by economists, planners and others. It is the market itself which determines what happens. Ultimately, you cannot buck the market: it is the market which decides. In different ways then agency is attributed to supra-human forces, which certain groups of humans are particularly well placed to know about. ${ }^{20}$

It should be clear that we are dealing with representations of how matters are claimed to be. In practice what happens is far more complex, variable and underdetermined than can be encapsulated in any single account. Such representations however play an important part in social action. Anthropologists' subject matter consists in large part of conflicting representations of actions and events, which directly affect future actions. How knowledge, power and agency is represented and responsibility attributed in different situations are therefore issues of interest; and their relevance to development forms the theme of this volume.

\section{Knowledge in practice}

An uncomfortable conclusion of the foregoing argument that theories are underdetermined and consist of representations of events with consequences for power and knowledge is that our own writings are implicated in this process. The work of academics affects what happens in various ways (Fabian 1991). Indeed there is the risk of these writings becoming part of the processes of hegemony, which they ostensibly set out to criticize. While there may be no neutral privileged position from which to capture a timeless truth, it does not follow that all representations are equal, or that nothing worthwhile can be said at all. A potentially useful task for anthropologists, as 'priests of humanistic plurality' (Richards p. 1), is to discuss critically how the relationship between expert knowledge and local knowledges work out in practice, as we understand it. This task is less easy than might seem. To construe local knowledge as systematic, or even to classify practices of dealing with the world as 'knowledge', is to domesticate practice by recourse yet again to a hegemonic epistemology. In this Introduction therefore, I neither can, nor wish to, delineate a general account of indigenous knowledges. To do so would be to replicate what I have criticized as the shortcomings of theories which claim such spurious generality and authority. What I can perhaps usefully do however is to examine how knowledge and agency is attributed, and how local knowledge is represented in the accounts of the contributors for the societies on which they work.

In practice, government officials representing the nation state play a central rle in attributing knowledge, ignorance and agency in the specification of development policy. Croll discusses how this worked in the post-revolutionary period between 1949 and 1976 in China. The example is the more interesting because, in a attempt to reverse the vision of knowledge as stemming from the educated lite, ostensibly it was portrayed as coming from 'the masses' - a term which significantly depersonalizes and diffuses agency. The new officials spoke of government learning from the limitless wisdom of the masses (Croll p. 1). 'In practice, what this formula demanded was that the scattered and unsystematic views of the masses be collected by the state, carefully

\footnotetext{
${ }^{20}$ In this account I have made use of an unpublished paper by Inden (n.d.) on how agency is constituted in social scientific theories. I elaborate the argument about agency in more detail in Hobart 1990.
} 
studied, co-ordinated, and translated into policy' (p. 2). As problems inevitably emerged in putting this reworked and decontextualized knowledge into practice, local populations came progressively to be defined as backward and ignorant by higher level administrative cadres. So they became represented not as agents, but as objects to be changed. Croll makes clear that such definitions of agency are a continual and contested process (p. 16) and must be understood in the social and political situations of their attribution.

An important instrument in codifying knowledge and fixing agency in practice is through law. As Benda-Beckmann points out however, although there is ample evidence that it is not so, 'the assumption that local law hinders development and that modern, western law is a prerequisite for development is one of the most deeply rooted ideas which informs development planning' (p. 2). Modern law becomes a 'magic charm' and local law is represented by developers as the 'scape-goat' for the failure of development. Agency is attributed to legal structures, through 'the idea that legal structures and norms directly cause or determine action and its consequences' (p. 2). Local law, among Minangkabau in Sumatra, is construed by officials concerned with development as an idealized, traditional system rather than as practices adjusted to changing circumstances. Villagers collaborate in this representation, but for quite different reasons. They make use of their perception of outsiders' ideas of traditional law as a means to articulate and legitimate their opposition to what they judge to be ignorant interference.

The extent to which different discourses are implicated in development is brought out by Arce and Long. In an extended case study, they examine the fate of a wellmeaning technician from the Mexican Ministry of Agriculture, who tried to represent the interests of local peasants, only to land up in a special remedial unit for 'troublemakers'. The farmers concerned lived by growing maize to eat and to feed cattle which they sold, as they did marijuana, through markets which were not government approved. They wanted a baling machine to increase productivity. Such a scheme however contravened the centrally planned policy, according to which they had been designated as a region for increased maize production for marketing through official channels. The farmers' 'underdevelopment' consisted in part in their not producing what, and as, was officially recognized. The difficulties also involved incompatibilities of knowledge in practice. The dictates of scientific agronomy militated against the crop rotation preferred by farmers, based on their experience of land conditions, in favour of the intensive use of pesticides and other chemicals in order to maximize productivity. The farmers objected that this increased crop disease in the long run (p. 10). The attempt of the agricultural official to aid his clients conflicted with the official policy of maize production and was treated as a challenge to his superior. The outcome confirmed the senior officials' ideas of the recalcitrance and stupidity of the peasants and their distrust in government. The failure of such centrallydirected planning is explained as the deficiency of the objects of development and of those whose task it is to implement policy.

The nature and difficulties of development are often portrayed spatially. The rejection of 'planning from above' in favour of a 'bottom up approach' does not however necessarily change matters, because the terms and the kind of action expected usually remain defined by 'superiors'. For a project from an outer province of Indonesia, Quarles van Ufford shows how 'there is a discrepancy between the official language of the development agency - the "bottom up approach", and local 
"homogeneity" - generating images of an active involvement of the peasants in the project activities, and the virtual absence of any such involvement at the local level as observed by some anthropologists' (p. 3). Expert knowledge is manifested here in a rhetoric of development and planning, which postulates a 'system' and suggests the rôles of the various participants are integrated, thereby creating the impression of manageability. The discourse of developers is often resistant to counter-evidence. When a team was sent to evaluate the project and reported that the local organizations set up neither really represented the peasants nor could function effectively, the report had to be buried. Many projects, Quarles van Ufford argues, appear to work because those to be developed are forced to be secretive and compartmentalize their lives ( $\mathrm{p}$. 11). There is an unbridgeable, but largely unappreciated, gap between the neat rationality of development agencies' representations which imagine the world as ordered or manageable and the actualities of situated social practices, an incommensurability tidied away in sociological jargon as 'unintended consequences'. The result is that the overlap of developers' and local discourses does not lead to improved communication, but to strain on those locals who are involved in both, and to techniques of evasion, silence and dissimulation. ${ }^{21}$

In different ways, discursively, some people are empowered to know and decide, others to implement the decisions, yet others not to speak, or not to be heard if they do. It is not just officials and developers who ascribe ignorance to locals; the reverse occurs. Ignorance is also Janus-faced. It may be used actively as a means of ignoring what others say and do. To speak of strategies of 'resistance' or 'denial' on the part of those designated as inferior is to assume that they recognize and submit to the hegemonic representation of them. For this reason I would suggest resurrecting the old English word 'obliviate', which implies an active ignoring of such representations and the prosecution of one's own point of view. ${ }^{22}$ Representatives of nation states may use means of trying to enforce government policies as a claim or demonstration of power. But, while planners tend to work with idealized, timeless and depersonalized versions

\footnotetext{
${ }^{21}$ Over the years, Philip Quarles van Ufford and I have argued amicably over the relationship between theorizing and participation in development, which is one of the constructive tensions of EIDOS. We both eschew the powerful fantasy that there is some notionally neutral theoretical eyrie from which to gaze dispassionately. But, as someone who has been directly involved in development projects, Quarles van Ufford is sensitive to the gap between detached academic understanding and the predicament of the participating 'expert', who cannot separate theory and practice and who must assume some sort of coherence and system, some rationale for the venture, in order to be able to function. I lack his kind of experience, but am concerned that such a position far from resolving the relationship of theory and practice perpetuates it, and its implications, under the name of necessity, involvement or commitment. Theorizing which is not thinking about an object is arguably arid; and the idea that practice does not involve theory is absurd.

${ }^{22}$ Finding a suitable term required a bibulous evening with Richard Fardon. One should not confuse silence or the absence of activity, as the two examples from Indonesia make especially clear, with a lack of agency. Not only is ostensible passivity potentially an active strategy, but in parts of the world it may be considered the hallmark of an agent (Burghart p. 5). The efficacy of silence has been picturesquely discussed by Baudrillard, who also makes the point that those constituted as 'the masses' may be part of our own societies.

That the silent majority (or the masses) is an imaginary referent does not mean that they don't exist. It means that their representation is no longer possible... No one can be said to represent the silent majority, and that is its revenge... The strategy of power has long seemed founded on the apathy of the masses. The more passive they were, the more secure it was. But this logic is only characteristic of the bureaucratic and centralist phase of power. And it is this which today turns against it: the inertia it has fostered becomes the sign of its own death' (1983: 20, 22, 23; emphases in the original).
} 
of an imagined world which is to be regulated, local people are often clearly aware of the personal, particular nature of the specification of policy or law in practice. Agency is rarely as clear-cut as its ascriptions suggest.

\section{Knowledge as practice}

The approach to local knowledge taken by those contributors who deal explicitly with the theme stresses the importance of treating knowing as a practical, situated activity, constituted by a past, but changing, history of practices. Such knowing requires evaluation by some measure like appropriateness to particular circumstances, rather than by its being true as such. The latter is often meaningless, when one is talking of a performance or knowledge which is so local that it could not be authentically codified (Burghart p. 2). The contributors make use of various recent authors who have, in different but related ways, been critical of the dominant approach of systematic epistemological theorizing. Several contributors cite the work of Giddens, whose account of structuration seeks to relate the institutional aspects of structure to action and agency $(1979,1984$; cf. Held \& Thompson 1989). Another relevant scholar is Bourdieu, who has argued for an analysis of action based on accepted social practices, or habitus $(1977,1990)$. One should note however that what the contributors understand by practice differs radically from the term as often used by developers, as the implementation of theory. This dichotomy is misleading, both in the postulated hierarchical relation of theory and practice, and in the failure to consider theorizing itself as a practice with its own history of usage, closure and consequences. ${ }^{23}$

In this sense, the approach of most of the contributions is broadly 'poststructuralist'. A drawback of much post-structural writing is that it is often programmatic, polemical and applied on a grand scale, which is ill-suited to fine grained studies. Also such writings remain largely eurocentric and dominated by textual, literary and linguistic concerns, so replicating in subtler form the presuppositions they set out to criticize. The attempt in this collection is to explore how some of the critiques and insights of post-structuralism or post-modernism can illuminate how knowledges are constituted and work as practices.

For these reasons, many of the contributors take issue with accounts which represent indigenous knowledge as systematic. This is a difficulty in different ways with two kinds of recent approach by anthropologists. The first is expounded in the essays in Brokensha et al., significantly titled Indigenous knowledge systems and development (1980). While the value of pointing out the importance of non-western kinds of knowledge is shared, the assumption that knowledge is systematic is diametrically opposed to the aim of the present work. The second approach is that of Clifford Geertz, elaborated in a collection of essays entitled Local knowledge (1983a). He argues for taking seriously 'local knowledge; local not just as to place, time, class and variety of issue, but as to accent - vernacular characterizations of what happens connected to vernacular imaginings of what can' (1983b: 215). The strength of his argument is in drawing attention to the need to treat what happens contextually in terms

\footnotetext{
${ }^{23}$ Developers who think that they are dealing commonsensically with theory-free practice in the "real world' are fooling themselves. As Collingwood remarked, such "realism" is based upon the grandest foundation a philosophy can have, namely human stupidity’ (1940: 34).
} 
of ideas and beliefs in the culture in question. ${ }^{24}$ The difficulties include his making use of a pervasive (western) dramaturgical metaphor of social action and assuming sufficient epistemological similarity as to make 'cultural translation' possible (see also Richards's critique of intellectualism below). Such accounts further exemplify their 'modernist' assumptions in ascribing agency to the interpreter and his or her superior understanding. While acknowledging local knowledges is important, whether it offsets the simultaneous, subtle hegemonizing of others is a moot point.

Most of the contributors share the view that the peoples they write about 'seem to work more through a body of practices - knowing how to do things and to react to changes, a set of practical procedures - than through a formal system of shared knowledge' (van Beek p. 2), which permits new practices to be adopted easily (p. 18). Significantly, in many instances, the terms for 'knowledge' are active verbs, as for Dogon who speak of 'knowing the word', which implies knowing both language and its use in accounts of their history (p. 17). Indeed without realizing how such knowing is historically constituted, including the long-standing threat of slavery, it is hard to understand why cultivation is oriented towards optimizing survival not maximizing harvests. Land is not treated as a homogeneous area but as finely differentiated; and, gerundively, as manageable, usable or otherwise in varying degree (p. 13).

The contrast between two kinds of agricultural knowledge in Andean potato farming is clearly drawn out by van der Ploeg. Drawing on Mendras's notion of l'art de la localité (1970), he notes that, to say that agricultural knowledge works from practice to practice, does not entail that such thinking is without theory, rather its syntax 'is not the nomological one of science; the scope is not a presupposed universe', but localized through labour as 'savoir-faire' (p. 2), in a process which 'presupposes an active, knowledgeable actor, who is actually the "agent" of the unity and constant interaction of mental and manual work' (p. 4). Whereas the model formally used for scientific plant-breeding starts with an ideal plant type, a genotype, as 'the point of departure for the specification of the required phenotypic conditions', Andean farmers deliberately mix and try out cultivars, so that the given phenotypic conditions are treated as 'starting points for the selection and adaptation of genotypes' (p. 9). The contrasting kinds of practice involve sharply different ways of representing time, causation, work and knowledge in practice.

Richards expresses a parallel concern with representations of time and intentionality. Farming systems researchers tend to regard intercropping as part of a predetermined design, which 'is to confuse intention and result', because the mix of crops is 'a completed performance', not a 'combinatorial logic' but 'sequential adjustment to unpredictable conditions'. For this reason the protected environments of research stations are "out of time" and "out of place", because "cultivation is a performance' in time and in place, not a rehearsal (p. 5). Attempts to consider situated practices as indigenous knowledge systems therefore involves 'a fallacy of misplaced abstraction - the making of intellectual mysteries out of situations and activities whose practical import is obvious to all but the observer' (p. 1). Instead Richards argues for treating agriculture - and by extension many other activities - as performances, which is not to invoke a dramaturgical metaphor but a practical image, as in a musical

\footnotetext{
${ }^{24}$ Anthropologists often rightly invoke context in situating or explaining action. Quite what context is however is elusive (Hobart 1985b). One should also note that essentializing and contextualizing are explanatory strategies with implications for power and are not confined to academics or experts (Hobart 1986: 138-51).
} 
performance. $^{25}$ Knowing in this sense is bringing skills learnt through practice and historically-derived experience to bear on a particular matter on a particular occasion. (We tend to overlook how much writing articles - and Introductions - is a similar craft skill which has to be learned.) Ability to speak is therefore an important form of knowing, 'a licence to perform' (p. 10). An implication of this point might be noted by developers, namely that learning to use a language well is not simply a matter of 'communicating' information, but being able to perform adequately.

People may represent what they know as systematic, for instance to express their distinctiveness and to rebuff others' claims to expert knowledge. Ascriptions of knowledge and ignorance involve peoples' perceptions of their social relations with one another and with outsiders, as Cohen makes clear (p. 7). ${ }^{26}$ The islanders of Whalsay in the Shetlands were successful in acquiring and making profitable an exceptionally modern fleet of fishing boats against expert and British government advice. To the locals it is not that outside experts are technically deficient. It is 'less a matter of what is known than of how it is known' (p. 4). 'Objective' knowledge must be reworked and considered reflexively in the light of peoples' historical experience and assessment of the present circumstances (p. 5). If the image of indigenous knowledge as systematic is fallacious, then the "popular proposition that successful innovation requires the "translation" of an alien idea into an indigenous idiom is revealed as hopelessly simplistic as well as being insidious' (p. 8). Cohen argues cogently that local knowledge exists as rival versions, which are not separable from the social conditions of their being known (p. 11), and which make possible a rich and dialectical argument. The fact that outsiders fail to appreciate this confirms their ignorance.

Burghart provides a detailed example of such cultural argument, which involved different versions of knowledge and concomitant ascriptions of agency, when he tried to improve the quality of water in a well in a town in south-eastern Nepal. I cannot reproduce the twists and turns of the argument here. Briefly Burghart shows how the Cobblers, whose well it was, treated him not as a social scientist, but as a Hindu lord 'with the commanding function of mind' ${ }^{27}$ Although the planned cleaning of the well was worked out between Burghart and the Cobblers, when the water turned bitter, he was converted from benevolent lord to a malevolent one. Burghart and the Cobblers were working with different versions of knowledge, which had different agentive implications. He 'went to them with an interest in their health; they were concerned, however, with their well-being' (p. 17); he took their complaint literally, when they were signalling the 'bitter' quality of their lives to someone they saw as a potential benefactor. There are incommensurabilities between discourses, in which constructions

\footnotetext{
${ }^{25}$ Fabian is similarly discontent with existing styles of anthropological analysis and sets out to treat social action, including the process of ethnography, as a complex of performances. He finds in the work of Victor Turner evidence of a move away from performance as dramaturgical to a less metaphoric and fraught usage (1990: 16-20).

${ }^{26}$ In similar vein, Parkin (1975) has argued that planned change depends crucially on an awareness of social divisions among those concerned. Where there is substantial agreement, it is easier to mobilize people about a specific 'plan'. Where there are serious differences, talk of the need for development becomes a 'symbol' to attempt to minimize the effects of such differences.

${ }^{27}$ In societies like China and India, ascriptions of the ability to know are not necessarily egalitarian and are far from fixed (Croll p. 16). Experts may know about or how to do things which others do not. Often knowing is considered a matter of degree and involves a chain of overlapping agency and patiency, whereas when knowledge is professionalized it often leads to those who are not designated as knowing being objects of that objectified knowledge.
} 
of agency and power are inseparable from representations of knowledge. In this light, the much-vaunted development strategy of relying on 'folk competence' was bound to run into difficulties. 'Rather than implying that successful development projects entailed a dual agency, research on folk competence held out yet again the hope to development workers of their ultimate control of the entire process' (p. 2).

\section{On ignorance}

In conclusion, what implications might this discussion of local and expert knowledges have for representations of ignorance? In one sense, the seemingly safe image of knowledge as growing entails a corresponding growth of ignorance. Ignorance may be construed in different ways however. It is not just 'not to know' but may suggest decay and the dismantling of a complex structure, or 'something more primordial... the cognitive facet of the moral term evil' (Vitebsky p. 1) ${ }^{28}$. Both knowledge and ignorance, as we have seen, are peculiarly ideal and timeless notions, which, rather than describing unambiguous states, are attributed to some people by others under particular circumstances, often with moral connotations. The relationship between different knowledges, as propounded and used by their adherents, is then often less dialectical than confrontational (or 'eristical', Collingwood 1942: 181-245). In other words, the proponents of one 'system' attempt to eliminate other knowledges, portray them and those who use them as not just wrong, but as benighted and bad.

What is excluded in such confrontations is the existence of doubt. In his essay, Vitebsky considers two ways of dealing with an important phenomenon where doubt and ignorance are inherent, namely death. He contrasts the Freudian psychoanalysis and the use of mediums among Sora in India to show how both attempt to deal with the unknown through dialogue, the former between analyst and patient, the latter between the mourner and deceased. He argues for considering forms of knowing not as true or false, but as appropriate to their knowers and users (p. 9). 'Yet at the same time local knowledge is often total, by virtue of the very fact that it is local' (p. 9). By contrast, the more medicalized, scientific and so universalized psychiatry becomes, the less it is able to cope with context 'because it applies to everywhere and nowhere, everybody and nobody' (p. 12). So ignorance differs in degree and kind according to the presuppositions of different knowledges.

Throughout this Introduction, I have argued for considering knowing, as do many of the peoples discussed in this volume, as a act which involves work as part of one's relationships with others. From this point of view, the use of abstract nouns to encapsulate such processes has interesting consequences. As Vitebsky notes, adjectives and verbs to do with knowing and being ignorant 'belong to the realm of attribute and agency, and the use of the nouns is a denial or diminution of this agency' (p. 7). The act of nominalizing converts processes of knowing into a commodity, 'knowledge', which becomes a thing in itself and turns people into objects or patients. 'In development reports, just as in medicine and clinical psychiatry, writers often make the abstract noun usurp the verb and strip it of its agency'. Or 'they turn it round and

\footnotetext{
${ }^{28}$ This last rendition catches some of the implications of the Hindu notion of tamas, desire or ignorance (often associated with darkness), which in Bali is often spoken of one of the three constituents, triguna, of human nature (the other two being sattva, purity or knowledge, and rajas, passion or emotion; Hobart 1986: 148-51). On their constitution in Indian Vaishnava texts as strands or substrata of all matter, see Inden 1985.
} 
replace its active voice with the passive and impersonal... In this way, it is not only agency which is diminished, but also causality, and hence responsibility' (p. 12)

Such nominalizing and abstraction are arguably central to the representation of scientific knowledge as hegemonic. One consequence is to turn people who were at least part agents into a backward and inert proletariat, the masses, who come to be constituted as passive objects to be developed. It is little wonder that attempts to develop them so often fail or go awry. The idea that modern education will solve the problem appears equally ill-founded. As Henry pointed out, behind the overt pedagogic aims of enlightening and broadening school childrens' knowledge lurks a 'hidden curriculum' in which fear and inadequacy are inculcated (1966: 182-321). Various organizations obviously have an interest in perpetuating a large population of passive political subjects and pliant consumers, who have been rendered uncritical, or at least silently and ineffectually so. The British government's educational policy for the state sector in the early 1990s stresses 'basic knowledge', designed to produce the 'gammas and deltas' of Huxley's Brave New World, the new labouring class who will mindlessly and uncomplainingly man the word processors of the future. 'Underdevelopment' is not a peculiar phenomenon of the evolution of distant countries, but a continuous process. One aim of this collection is to argue that knowledge is not what it is often represented to be and to address the problems and implications of the growth of ignorance.

\section{BIBLIOGRAPHY}

Alatas, S.H. 1977. The myth of the lazy native: a study of the image of the Malays, Filipinos and Javanese from the 16th to the 20th century and its function in the ideology of colonial capitalism. London: Cass.

Aristotle, 1941. Nichomachean ethics. In The basic works of Aristotle. ed. R. McKeon, New York: Random House.

Bailey, F.G. 1957. Caste and the economic frontier. Manchester: Univ. Press.

- 1969. Stratagems and spoils. Oxford: Blackwell.

Bakhtin, M.M. 1986. The problem of speech genres. In Speech genres and other late essays. trans. V.W. McGee, eds. C. Emerson \& M. Holquist, Austin: Univ. of Texas Press.

Barth, F. ed. 1963. The role of the entrepreneur in social change in northern Norway. Bergen: Univ. Press.

- 1966. Models of social organization. Occasional Paper 23, London: Royal Anthropological Institute.

Bhaskar, R. 1979. The possibility of naturalism: a philosophical critique of the contemporary human sciences. Sussex: Harvester.

- 1989. On the possibility of social scientific knowledge and the limits of naturalism. In Reclaiming reality: a critical introduction to contemporary philosophy. London: Verso.

Bourdieu, P. 1977. Outline of a theory of practice. trans. R. Nice, Cambridge: Univ. Press.

- 1990. The logic of practice. trans. R. Nice, Cambridge: Polity Press. 
Brokensha, D.W., Warren, D.M. \& Werner, O. eds. 1980. Indigenous knowledge systems and development. Lanham, M.D.: Univ. Press of America.

Chambers, R. 1983. Rural development: putting the last first. London: Longman. Collingwood, R.G. 1933.An essay on philosophical method. Oxford: Clarendon Press.

$-1940$. An essay on metaphysics. Oxford: Clarendon Press.

$-1942$. The new Leviathan or man, society, civilization and barbarism. Oxford: Clarendon Press.

Dilley, R. ed. in press. Contesting markets. Edinburgh: Univ. Press.

Evans-Pritchard, E.E. 1937.Witchcraft, oracles and magic among the Azande. Oxford: Clarendon Press.

Fabian, J. 1983. Time and the other: how anthropology makes its object. New York: Columbia Univ. Press.

- 1990. Power and performance: ethnographic explorations through proverbial wisdom and theater in Shaba, Zaire. Madison: Univ. of Wisconsin.

- 1991. Dilemmas of critical anthropology. In Constructing knowledge: authority and critique in social science. eds. L. Nencel and P. Pels, London: Sage.

Fardon, R. ed. 1990. Localizing strategies: regional traditions of ethnographic writing. Edinburgh: Scottish Academic Press and Washington: Smithsonian Institution.

Feyerabend, P. 1975. Against method: outline of an anarchistic theory of knowledge. London: Verso.

Foucault, M. 1961. Folie et draison, histoire de la folie l'Áge classique. Paris: Plon. 1967. Madness and civilization: a history of insanity in the age of reason. trans. R. Howard, Tavistock: London.

- 1966. Les mots et les choses: une archologie des sciences humaines. Paris: Gallimard. 1970. The order of things: an archaeology of the human sciences. trans. A.M. Sheridan, London: Tavistock.

- 1969. L' archologie $d u$ savoir. Paris: Gallimard. 1972. The archaeology of knowledge. trans. A.M. Sheridan, London: Tavistock.

- 1975. Surveiller et punir: naissance de la prison. Paris: Gallimard. 1977. Discipline and punish: the birth of the prison. trans. A. Sheridan, Harmondsworth: Penguin.

- 1976. La volonté de savoir. Paris: Gallimard. 1984. The history of sexuality I. trans. R. Hurley, Harmondsworth: Penguin.

- 1971. L'ordre du discours: leçon inaugural au Collge de France.] Paris: Gallimard. 1981. The order of discourse. trans. I. McLeod. In Untying the text: a post-structuralist reader. ed. $\mathrm{R}$. Young, London: Routledge \& Kegan Paul.

Frank, A.G. 1969. Capitalism and under-development in Latin America. London: Monthly Review Press.

Geertz, C. 1983a. Local knowledge: further essays in interpretive anthropology. New York: Basic Books. 
$-1983 b$.

Giddens, A. 1976. New rules of sociological method: a positive critique of interpretative sociologies. London: Hutchinson.

$-1979$.

$-1984$.

Ways of worldmaking. Hassocks: Harvester Press.

Gramsci, A. 1988. A Gramsci reader: selected writings 1916-1935. ed. D. Forgacs, London: Lawrence and Wishart.

Habermas, J. 1978. Knowledge and human interests. 2nd. edn, London: Heinemann.

Hacking, I. 1983. Representing and intervening: introductory topics in the philosophy of natural science. Cambridge: Univ. Press.

Hacking, I. 1990. The taming of chance. Cambridge: Univ. Press.

Hahn, F. \& Hollis, M. eds. 1979. Philosophy and economic theory. Oxford: Univ. Press.

Heath, A. 1976. Rational choice and social exchange: a critique of exchange theory. Cambridge: Univ. Press.

Held, D. \& Thompson, J.B., 1989. Social theory of modern societies: Anthony Giddens and his critics. Cambridge: Univ. Press.

Henry, J. $1966 . \quad$ Man against culture. London: Tavistock.

Hesse, M. 1978. Theory and value in the social sciences. In Action and interpretation: studies in the philosophy of the social sciences. eds. C. Hookway and P. Pettit, Cambridge: Univ. Press.

Hobart, M. 1985a. Anthropos through the looking-glass: or how to teach the Balinese to bark. In Reason and morality. ed. J. Overing, ASA Monographs in Social Anthropology 24, London: Tavistock.

- 1985b. Is God evil? In The anthropology of evil. ed. D.J. Parkin, Oxford: Blackwell.

$-1986$.

$-1990$.

- forthcoming.

Hollis, M. 1970.

Hollis, M. 1982. Thinker, thespian, soldier, slave? assumptions about human nature in the study of Balinese society. In Context, meaning, and power in Southeast Asia. eds. M. Hobart \& R.H. Taylor, Ithaca, New York.: Cornell Southeast Asia Program.

The patience of plants: a note on agency in Bali. Review of Indonesian and Malaysian affairs 24, 2.

The windmills of criticism: on understanding theatre in Bali. In Political cultures of criticism] eds. R. Burghart \& V. Das.

The limits of irrationality. In Rationality. ed. B. Wilson, Oxford: Blackwell.

The social destruction of reality. In Rationality and relativism. eds. M. Hollis and S. Lukes, Oxford: Blackwell.

- \& Lukes, S. eds. 1982. Rationality and relativism. Oxford: Blackwell.

Inden, R. 1985. Hindu evil as unconquered Lower Self. In The anthropology of evil. ed. D. Parkin, Oxford: Blackwell.

$-1990$.

- n.d.
Imagining India. Oxford: Blackwell.

Social scientific thinking; or four ideas (and more) of human nature. Unpublished paper. 
Kuhn, T.S. 1962. The structure of scientific revolutions. Chicago: Univ. Press.

Laclau, E. 1971. Feudalism and capitalism in Latin America. New left review. 67: 19-38.

Lakatos, I. \& Musgrave, A. eds. 1970. Criticism and the growth of knowledge: proceedings of the international colloquium in the philosophy of science, London 1965. Vol. 4, London: Cambridge Univ. Press.

Lakoff, G. \& Johnson, M. 1980. Metaphors we live by. London: Univ. of Chicago Press.

Long, N. 1977. An introduction to the sociology of rural development. London: Tavistock.

Lukes, S. 1973a. Émile Durkheim: his life and work, a historical and critical study. Middlesex: Allen Lane.

Lukes, S. 1973b. Individualism. Oxford: Blackwell.

Mason, P. 1990. Deconstructing America: representations of the Other. New York: Routledge.

Mendras, H. 1970. The vanishing peasant: innovation and change in French agriculture. Cambridge: Univ. Press.

Moore, W.E. 1963. Social change. Englewood Cliffs, N.J.: Prentice-Hall.

Newton-Smith, W. 1982. Relativism and the possibility of interpretation. In Rationality and relativism. eds. M. Hollis and S. Lukes, Oxford: Blackwell.

Ortony, A. ed. 1979. Introduction to Metaphor and thought. Cambridge: Univ. Press.

Overing, J. ed. 1985. Reason and morality. ASA Monographs in Social Anthropology 24, London: Tavistock.

Pagden, A. 1982. The fall of natural man. Cambridge: Univ. Press.

Paine, R. 1974. $\quad$ Second thoughts about Barth's models. Occasional Paper 32, London: Royal Anthropological Institute.

Parkin, D.J. 1975. The rhetoric of responsibility: bureaucratic communication in a Kenya farming area. In Political language and oratory in traditional society. ed. M. Bloch, London: Academic Press.

Peirce, C.S. 1984. Some consequences of four incapacities. In Writings of Charles S. Peirce: a chronological edition. Vol. 2, Bloomington: Indiana Univ. Press.

Quarles van Ufford, P. 1985. Rationalities and development in Java. In Development and its rationalities. eds. C.A. van Peursen \& M.C. Doeser, Amsterdam: Free Press.

- \& Long, N. forthcoming. Policy and practice. London: Routledge.

Quine, W.V.O. 1953. Two dogmas of empiricism. In From a logical point of view. Cambridge, Mass.: Harvard Univ. Press.

Reddy, M. 1979. The conduit metaphor - a case of frame conflict in our language about language. In Metaphor and thought. ed. A. Ortony, Cambridge: Univ. Press.

Rorty, R. 1980. Philosophy and the mirror of nature. Oxford: Blackwell.

Ryle. G. 1949. The concept of mind. London: Hutchinson.

Said, E. 1978. Orientalism. London: Routledge \& Kegan Paul.

Salmond, A. 1982. Theoretical landscapes. On a cross-cultural conception of knowledge. In Semantic anthropology. ed. D. J. Parkin, London: Academic Press. 
Shapiro, J.J. 1972. Translator's Notes to J. Habermas, Knowledge and human interests. London: Heinemann.

Smelser, N.J. 1963. Mechanism of change and adjustment to change. In Industrialization and society. eds. B.F. Hoselitz \& W.E. Moore, The Hague: Mouton.

Smith, A.D. 1973. The concept of social change: a critique of the functionalist theory of social change. London: Routledge \& Kegan Paul.

Taylor, C. 1985. Philosophy and the human sciences: philosophical papers 2. Cambridge: Univ. Press.

Timberlake, L. 1988. Sustained hope for development. New scientist 7th. July 1988.

Tribe, K. 1978. Land, labour and economic discourse. London: Routledge \& Kegan Paul.

Vitebsky, P. 1992. Landscape and self-determination among the Eveny: the political environment of Siberian reindeer herders today. In Bush base, forest farm: culture, environment, development. eds. E. Croll \& D. Parkin, London: Routledge.

Volosinov, V.N. 1973. Marxism and the philosophy of language. trans. L. Matejka \& I.R. Titunik, Cambridge, Mass.: Harvard Univ. Press.

Wallace, A.F.C. 1961.Culture and personality. New York: Random House.

Wilson, B. ed. 1970. Rationality. Oxford: Blackwell.

Winch, P. 1970. Understanding a primitive society. In Rationality. ed. B. Wilson, Oxford: Blackwell. 